RU Аксиологический концепт ГУМАННЫЙ ЧЕЛОВЕК в русской лингвокультуре

Бирюлина Е. А.

Аннотация. Цель исследования - раскрыть структуру и содержание аксиологического концепта ГУМАННЫЙ ЧЕЛОВЕК в русской традиционной и книжно-письменной лингвокультуре на разных этапах его жизненного цикла. Эмпирической базой исследования являются данные лингвистических экспериментов. Анализ осуществляется с использованием методики концептуального анализа, которая позволяет последовательно описать понятийный, образный и аксиологический слои концепта. Научная новизна исследования заключается в раскрытии структуры и содержания аксиологического концепта ГУМАННЫЙ ЧЕЛОВЕК в русской лингвокультуре. В результате показано, что концепт ГУМАННЫЙ ЧЕЛОBEK, зародившийся в русской лингвокультуре в середине XIX в., изменяется под воздействием экстралингвистических факторов на разных этапах своего жизненного цикла. Также показано, что в структуре данного концепта отсутствует четкая граница между понятийным и аксиологическим слоями.

\title{
EN Axiological Concept HUMANE PERSON in Russian Linguoculture
}

\author{
Biryulina E. A.
}

Abstract. The purpose of the study is to shed light on the structure and content of the axiological concept HUMANE PERSON in Russian traditional and literary written linguoculture at different stages of its life cycle. Data of linguistic experiments constitute the empirical basis of the study. The analysis is carried out using the methodology of conceptual analysis, which makes it possible to consistently describe the notional, image-bearing and axiological layers of the concept. Scientific novelty of the study lies in shedding light on the structure and content of the axiological concept HUMANE PERSON in Russian linguoculture. As a result, it has been shown that the concept HUMANE PERSON, which emerged in Russian linguoculture in the middle of the XIX century, changes under the influence of extralinguistic factors at different stages of its life cycle. It has been shown also that in the structure of this concept, there is no clear boundary between the notional and axiological layers.

\section{Введение}

Актуальность работы обусловлена особой научной и культурной значимостью раскрытия содержания аксиологического концепта ГУМАННЫЙ ЧЕЛОВЕК в русской традиционной и книжно-письменной лингвокультурах в рамках современной антропоцентрической парадигмы. Исследования такого рода дают возможность углубить представления о нравственно-этических воззрениях русского народа, о национальных особенностях человеческих взаимоотношений для понимания сути национальных лингвокультур.

В современной лингвистике получили особую значимость работы, посвященные исследованию ценностной картины мира, а также аксиологических концептов (Алефиренко, 2016; Арутюнова, 2004; Долевец, 2008; Никитина, 2014; Мокрушина, 2008). Аксиологические концепты представляют собой такую разновидность лингвокультурного концепта, в которой посредством языка закодированы морально-нравственные и духовные ориентиры народа. Они являются важнейшими единицами национальной концептосферы и характеризуются целостностью, многомерностью и возможностью эволюционировать с течением времени. Особое место среди аксиологических концептов занимают те, которые характеризуют человека. В настоящее время на материале разных лингвокультур исследованы такие концепты, как ДРУГ (Лукашова, 2001), ХОРОШИЙ ЧЕЛОВЕК (Береснева, 2016), ПЛОХОЙ ЧЕЛОВЕК (ЦиПотан, 2019), УДАЧЛИВЫЙ ЧЕЛОВЕК (Мархиева, 2011), СОВРЕМЕННЫЙ ЧЕЛОВЕК (Розман, 2021), ГЛУПЫЙ ЧЕЛОВЕК (Нурова, 2014), СОВРЕМЕННАЯ ДЕВУШКА (Наумова, 2016).

Несмотря на наличие исследований, посвященных аксиологическим концептам, в том числе концептам, характеризующим человека, в отечественной лингвистике до сих пор остается нераскрытым содержание такого важнейшего для русской лингвокультуры концепта, как ГУМАННЫЙ ЧЕЛОВЕК. 
Для достижения поставленной проблемы решаются задачи: 1) провести историко-этимологический анализ слова-имени концепта «гуманный» в русском языке; 2) разграничить содержание смежных аксиологических концептов ЧЕЛОВЕКОЛЮБИВЫЙ ЧЕЛОВЕК и ГУМАННЫЙ ЧЕЛОВЕК в русской нацИонаЛьноЙ концептосфере; 3) изучить и описать содержание понятийного, аксиологического и образного слоев концепта ГУМАННЫЙ ЧЕЛОВЕК.

Объектом исследования выступают структура и содержание аксиологического концепта ГУМАННЫЙ ЧЕЛОВЕК, предметом - языковые средства экспликации понятийного, образного и аксиологического слоев концепта.

Материалом исследования послужили данные Национального корпуса русского языка (НКРЯ, 2021), а также данные лингвистических экспериментов, проведенных в различных институтах Сибирского федерального университета (Институте филологии и языковой коммуникации, Институте управления бизнес-процессами, Институте экономики, государственного управления и финансов и Юридическом институте). В экспериментах приняли участие 207 человек в возрасте от 17 до 22 лет. Все участники эксперимента отнесли себя к представителям русской лингвокультуры.

Объем привлеченного для анализа материала составил 137 мини-сочинений и 658 ассоциатов на предложенные слова-стимулы.

В статье применяются следующие методы: 1) на этапе сбора материала применялись метод выборки контекстов для словосочетания «гуманный человек» из Национального корпуса русского языка, метод свободного ассоциативного эксперимента, в рамках которого информанты должны были привести реакции на словосочетание-стимул «гуманный человек», методика дописывания заданной фразы «Гуманного человека я могу сравнить с...», методика мини-сочинения на заданную тему «Мои размышления о гуманности»; 2) на исследовательском этапе - методика лингвокультурологического анализа концепта и метод лингвистического описания.

Теоретической базой исследования послужили публикации отечественных лингвистов, в которых рассматриваются ценностные доминанты в языке, аксиологические концепты и ценностная картина мира (Алефиренко, 2016; Арутюнова, 2004; Воркачев, 2004).

Практическая значимость работы заключается в возможности применения ее результатов как для дальнейших исследований русской лингвокультуры, так и при изучении аксиологических концептов в вузовских курсах лингвокультурологии.

\section{Основная часть}

Оценочное прилагательное «гуманный» выступает ключевым звеном для понимания и описания содержания структуры концепта ГУМАННЫЙ ЧЕЛОВЕК. В связи с этим прежде всего проведем историко-этимологическое исследование лексемы «гуманный».

В русский язык слово «гуманный» было опосредованно заимствовано из латинского языка через немецкий язык (от лат. humānitās) в середине XIX в. (Шанский, 1972, с. 198; Фасмер, 1986, с. 258). Впервые оно было зафиксировано в «Карманном словаре иностранных слов русского языка» Н. С. Кирилова (1845) в 1845 г., в словарной статье указано следующее: «Гуманный. Все, что имеет интерес прямо человеческий и для человечества. Особенно употребляют это слово, говоря о произведении литературы, о правительственном учреждении, о политическом событии, которые должны иметь влияние на жизнь и направление людей, в которых выразилось сознание истинных требований жизни общественной или частной» (с. 46). Содержание словарной статьи свидетельствует о том, что сфера использования слова «гуманный» в 40-е годы ХІХ в. ограничивается книжнописьменной сферой употребления. В. Г. Белинский (1982) в письме к Бакунину в апреле 1841 г. использует слово «гуманный» как синоним к слову «человечный»: «Да, теперь уже не Гегель, не философские колпаки - мои герои; сам Гете велик как художник, но отвратителен как личность; теперь снова возникли передо мною во всем блеске лучезарного величия колоссальные образы Фихте и Шиллера, этих пророков человечности (гуманности), этих провозвестников царства божия на земле, этих жрецов вечной любви и вечной правды не в одном книжном сознании и браминской созерцательности, а в живом и разумном Tat.». Однако современники вхождения слова «гуманный» в состав русского языка осознавали тонкую семантическую разницу между словами «гуманный» и «человеколюбивый». В словаре В. И. Даля (1998), опубликованном в середине XIX в., «гуманный» трактуется как заимствованное слово - лексикограф приводит помету «лат.» (латинское) и подчеркивает, что свойство гуманности характерно для просвещенных людей: «Гуманный - лат. человеческий, человечный, людский; свойственный человеку истинно просвещенному (выделено автором статьи. - Е. Б.); человеколюбивый, милостивый, милосердый». Для слова «человеколюбивый» лексикограф дает следующую дефиницию: «Человеколюбие, любовь к ближнему, состраданье, милосердие» - и приводит следующие примеры: «Человеколюбный, человеколюбивый государь. Нет супротив Бога человеколюбциа!».

Судя по приведенным контекстам неологизм середины XIX в. «гуманный» и его синонимы «человечный», «человеколюбивый», «милосердный» различаются оттенками значения.

Примеры использования лексемы «чєловъколюбиє» в текстах церковно-славянской и древнерусской письменности свидетельствуют о том, что данное слово прежде всего ассоциировалось в языковой картине мира православного человека с человеколюбивым Богом. Коннотативными компонентами лексического значения слова «человеколюбие» являются «помощь» и «забота». Эти качества прежде всего связывались с Богом, а также с теми людьми, которые, являясь православными, проявляли милосердие к другим: «Добро человъколюбия, кормление убогих, и человеческой помощи (фı $\alpha v \theta \rho \omega \pi i ́ \alpha)$. Гр. Наз. ХІ в. 77. Порученный от человъколюбия резрешати и взяти. Ефремовская кормчия Василию Великому 74. И кто не подивится бесчисленного его человъколюбию. “Слово о законе и благодати” Иллариона (Сбор. 1414 2., л. 41). Яви человеколюбие свое. Нест. 
Бор. Гл. 29. О неизреченное человеколюбие. Радз. л. 6693 г. Прилучися прийти на них по человеколюбию Божию праведному суду. Новг. І л. 6860 г. Прочее же оставити на человЊколюбие Божее. Кипр. м. Посл. иг. Аф. 1390 г.» (Срезневский, 1893, с. 1490).

Представления о человеколюбивом Боге, заботе и помощи ближнему отражены в дефиниции Словаря Академии Российской (1974): «Человеколюбие - любовь к человеческому роду, любовь к ближнему, благодетельное возчувствование ко всему роду человеческому» (с. 1253). Дефиницию к прилагательному «человеколюбивый» словарь не фиксирует. Таким образом, в русской лингвокультуре прослеживается разделение на два смежных аксиологических концепта - ЧЕЛОВЕКОЛЮБИВЫЙ БОГ и ЧЕЛОВЕКОЛЮБИВЫЙ ЧЕЛОВЕК. Содержание последнего выражается в абстрактной и жертвенной любви человека к своему ближнему, ко всем людям, а также в помощи другим.

Появление нового слова «гуманный» свидетельствует о формировании в русской лингвокультуре второй пол. XIX в. особого концепта - ГУМАННЫЙ ЧЕЛОВЕК, содержание которого отличается от концепта ЧЕЛОВЕКОЛЮБИВЫЙ ЧЕЛОВЕК. Базовым понятиЙным признаком концепта ГУМАННЫЙ ЧЕЛОВЕК на первых этапах его жизненного цикла является свойство «культурного и образованного человека»: Учителя тоже помнили и помнят молодого учителя словесности, постоянно упрекавшего их в жестокосердии и неуменье передавать взятого на себя предмета. Все изменилось на время под благотворным влиянием этого умного, гуманного человека. В учениках своих он умел развить охоту к чтению, постоянно прочитывая сам различные книги и, кроме того, снабжая ими желающих. Уроки всегда рассказывались им с такою ясностью и так понятно, что каждый мог повторить их, не прочитывая по книге. Кроме своего предмета, он сообщил нам необходимые понятия почти о всех науках, показав в то же время метод к изучению и степень важности каждой во всеобщем знании [М. А. Воронов. Детство и юность (1862)]; Как человек просвещенный, гуманный, как светлая личность, не как какой-нибудь, Сергей Сергеевич, - вы сумеете все понять... [Андрей Белый. Петербург (1913-1914)]; Это пришли рабы воскресшие, которые строили пирамиды, пришли со своими тысячелетними мозолями и слезами за любовью, за советом и помощью, как к образованному и гуманному человеку $\boldsymbol{X X}$ века, а вы как с ними поступили? [Л. Н. Андреев. Губернатор (1905)]; Все, конечно, избявили согласие и скоро вышли из капитанской каюты как-то духовно приподнятые, полные жажды знания и добра, горевщие искренним желанием быть не только отличными моряками, но и образованными, гуманными людьми [К. М. Станюкович. Вокруг света на Коршуне (1895)].

В первой половине XX в. в понятийном слое концепта актуализированы признаки «культурный», «внимательный к чужой личности», «отзывчивый». В словаре Д. Н. Ушакова к слову «гуманный» приведены следующие примеры: «Гуманность обращения. Гуманное отношение, гуманный характер. Несмотря на строгость, его любили за гуманность. Гуманный человек. Гуманный поступок. Поступать, относиться гуманно (нареч.)» (Толковый словарь..., 1994, с. 639).

Во второй половине ХХ в. в словарной статье ГУМАННЫЙ в первом издании словаря С. И. Ожегова (1949) помимо признаков «отзывчивый» и «культурный», фиксируется также концептуальный признак «человечный»: «человечный, отзывчивый, культурный. Гуманное отношение» (с. 136). В более поздних изданиях этого словаря слово «гуманный» представлено с толкованием: «Направленный на благо других; человеколюбивый и отзывчивый. Гуманное поведение. Гуманные цели. Поступить гуманно (нареч.)» (Ожегов, Шведова, 2002, с. 149). Это может свидетельствовать о том, что концептуальный признак «культурный» уходит на периферию понятийного поля рассматриваемого концепта.

В словаре под реакцией С. А. Кузнецова в дефиниции «гуманный» подчеркиваются такие признаки, как «человеколюбивый, человечный в поступках и отношениях» и «проникнутый гуманизмом; основанный на принципах гуманизма». В словарной статье приводятся следующие иллюстрации: «Быть гуманным. Гуманен в обращении с больными. Г-ые цели. Из гуманных соображений. Г-ое обращение с заключенными. Г-ая профессия (обычно о профессии врача, учителя и т.п.). Г-ые методы, способы (не причиняющие боли, страдания). Гуманно, нареч. (2 зн.). Поступить г. Г. обращаться с кем-л. Г. мыслить. Проявить г.» (Большой толковый словарь..., 2003). Следует отметить, что указанные в Большом толковом словаре русского языка под ред. С. А. Кузнецова «принципы гуманизма» в русской лингвокультуре второй половины 90-х годов XX века воспринимались двояко: с позиции европейского, либерального и социалистического (марксистского) гуманизма. С марксистской точки зрения к принципам гуманизма относятся: признание человека высшей ценностью жизни, уважение к его труду, внимание к его потребностям и саморазвитию, забота о его интересах, преодоление индивидуализма и эгоизма в обществе, а также непримиримое отношение к отрицательным качествам человека и борьба за их искоренение (Петросян, 1955, с. 45-58). С точки зрения западноевропейского гуманизма к гуманистическим принципам прежде всего относятся индивидуализм и свобода отдельно взятой личности (Сандагийн, 2004). Это обстоятельно оказывает влияние на содержание концепта ГУМАННЫЙ ЧЕЛОВЕК в русской национальной лингвокультуре.

В словарях рубежа тысячелетий подчеркивается, что значение лексемы «гуманный» прежде всего связывается с понятиями «человечный, человеколюбивый, относящийся к людям отзывчиво, чутко и с уважением к их человеческому достоинству» (Черных, 1993, с. 226); «проникнутый любовью к человеку, уважением к человеческой личности» (Ефремова, 2000).

На основании проанализированных словарных дефиниций в содержании исследуемого аксиологического концепта ГУМАННЫЙ ЧЕЛОВЕК в русской лингвокультуре XX - нач. XXI в. возможно выделить три базовыХ понятийных признака:

1) любит других людей: Сам он был в высшей степени гуманным человеком, сцены жестокости, которые приходилось ему наблюдать во время путешествий на суше и на корабле, глубоко возмущали его [Т. А. Фаворская. Фаворские. Жизнь семьи университетского профессора. 1890-1953. Воспоминания (2019)]; 
2) оказывает помощь и моральную поддержку другим людям: И еще он был гуманист в высоком смысле этого слова. Он помогал чем мог нашей семье и семьям других бывших людей. Когда кто умирал, он утешал их родных; кого-то арестовывали - он хлопотал [С. М. Голицын. Записки уцелевшего (1980-1989)];

3) относится с уважением к человеческому достоинству и личности: Я припал к щели. Мима в одиночестве отрешенно царапал плаху. Убить рыбу. Я все думаю, думаю, и мне начинает казаться, что гуманным и умным людям, которые будут жить после нас, если только вообще будут жить, - трудно будет понять, как же это все-таки могло быть, - постичь зарождение самой мысли убийства, тем более массового. Убить. Как это? Зачем? [Анатолий Кузнецов. Бабий яр (1965-1970)]; И я тебе скажу, почему война так действует на людей! Всетаки человек только в древности был зверем и все время двигался по гуманной линии. Сейчас нет ни виселиц, ни плах, ни гильотин! И гораздо гуманней был человек в этом году, скажем, чем двадиать или даже десять лет назад! [Венедикт Ерофеев. Записки психопата (1956-1957)].

В результате проведенных лингвистических экспериментов удалось уточнить содержание концепта ГУМАННЫЙ ЧЕЛОВЕК в языковой картине мира современных носителей русской лингвокультуры. Данные, полученные с помощью методики дописывания фразы «Как всякий гуманный человек, он...», позволяют уточнить понятийные признаки концепта ГУМАННЫЙ ЧЕЛОВЕК:

1) ценит и уважает человеческую личность и ее права (он всегда уважительно относится ко всем людям, уважительно относится к другим, уважает мнение каждого, проявил уважение к чужой точке зрения, уважает каждого, уважает других людей, осознает ценность жизни людей, уважает права и свободы других людей);

2) помогает другим людям (должен помогать людям вокруг него, помогает людям, помогал ближним, проявил симпатию к этому бедному существу, должен помогать даже тем, кого ненавидит, не оставил его в беде, каждый день помогает людям и заботится о том, чтобы всем вокруг него было комфортно, не смог пройти мимо, может помочь своему напарнику);

3) не проявляет жесткость и не вредит другим (избегал насилия, спокойно объяснил, почему нельзя так поступать и не стал наказывать, не смог направить оружие на невинного человека, не стал бить несчастного ногами);

4) добр по отношению к другим людям (добр по отношению к окружающим и с пониманием относится к их проблемам и переживаниям, добр и отзывчив, был очень добрым и сочувствующим, был добрым);

5) сострадает и сопереживает другим людям (имеет сострадание, способен к состраданию и милосердию, жалеет людей, с сочувствием относился к нуждающимся, бережет других, думает о других, не стал давить на него);

6) толерантно и снисходительно относится к другим людям и культурам (толерантно относится к другим людям, относится хорошо ко всем культурам, хорошо относится к любому человеку, независимо от его особенностей, относится ко всем людям одинаково, несмотря на какие-либо отличия в образе жизни или прочем, обязан проявлять терпимость);

7) любит других людей (любит людей);

8) справедливо относится к другим (поступает справедливо, не судит, а пытается понять, никогда не осуждал поступки других);

9) милосердно относится к животным (никогда не пройдет мимо голодной собаки).

Среди ответов были также получены единичные оценочные реакции, эксплицирующие положительную этическую оценку (эмпатичный, снисходителен, великодушный, благородный, терпимый, отзывчивый, воспитанный, человечный, человеколюбивый).

Особенностью структуры рассматриваемого аксиологического концепта является то, что граница между понятийным и аксиологическим слоем размыта и практически все важные понятийные признаки концепта являются оценочными.

Для уточнения содержания аксиологического концепта ГУМАННЫЙ ЧЕЛОВЕК нами был проведен лингвистический эксперимент, сутью которого являлось написание сочинения-рассуждения на тему «Мое представление о гуманности». Анализ полученных сочинений подтверждает корректность выделенных понятийных признаков концепта ГУМАННЫЙ ЧЕЛОВЕК, а также еще больше расширяет и углубляет представление о содержании понятийного и тесно с ним связанного оценочного слоя изучаемого концепта:

1. Ценит и уважает человеческую личность и ее права: Гуманный человек уважает человеческую личность, принимает ее такой, какой она есть; Гуманный человек всегда относится к другим с уважением, эти люди всегда добры и внимательны к другим, о чем свидетельствуют их гуманные поступки; Такие люди уважают окружающих и не оставят их в беде, потому что всегда попытаются помочь всеми силами; в классическом понимании гуманный человек - человеколюбивый, с уважением относящийся к личности человека, но в большинстве своем это утопия, мы можем кого-то недолюбливать, хотя и не показываем это в большинстве случаев; Я считаю, что на сегодняшний день существует множество гуманных людей, а именно таких: уважающие других людей, не причиняющие другому человеку вреда; Люди, которым не все равно на окружающих, которые не могут пройти мимо и не помочь, которые с пониманием, уважением и «на равных» относятся к любому человеку независимо от возраста, пола и ориентации - это и есть гуманные люди; Следовательно, гуманным человеком можно назвать того человека, который ценит жизнь, как человеческую, так и любого другого существа, и который всегда готов прийти на помощь нуждающемуся, выслушать и поддержать, который ценит и уважает природу; Гуманный человек - это человек, который любит и уважает других людей, заботится о них, по-доброму относится ко всему живому; Для меня гуманным является тот, для которого человек является высшей ценностью; Но что бы ни происходило, нужно всегда оставаться человеком, гуманным человеком. А именно относиться ко всем с уважением; Для меня гуманный человек - это личность, которая уважает себя, ведь без этого человек не может уважать других, окружающих его людей; На мой взгляд, гуманный человек - тот, который относится 
к другим людям с уважением, любовью, добротой; Человек, обладающий этим качеством - это тот, кто выделяет ценности человеческой личности и признает его право на свободу, развитие, любовь, счастье, самовыражение, каким бы оно ни было и т.д.; Гуманный человек всегда уважает личность другого, он может сочувствовать другому и относиться с пониманием; Для меня гуманный человек - это тот, кто хорошо и уважительно относится к окружающим его людям; Быть гуманным человеком - значит поступать гуманно, стремиться не причинять вреда живым существам, помнить о достоинстве людей, быть добросердечным в своих действиях, но справедливым; Гуманный человек искренне любит и уважает других людей, он не совершает дурного поступка, намеренной подлости или предательства. Сейчас очень мало таких людей; На мой взгляд, гуманный человек - это человек, проявляющий уважение к личности других людей, а также стремящийся своими поступками нанести как можно меньше вреда другим людям; Такой человек будет с уважением относиться к другим людям, и если он где-то был не прав, то просто извинится, а не начнет словесную перепалку, которая может перейти в драку; уважает людей; человек, который ценит, уважает других людей, принимает традиции, обычаи и нормы других народов; человек, который уважает других людей; человек, уважающий других людей; человек, который уважает, любит и понимает другого; человек, который проявляет внимание и уважение к другим людям; человек, который [умеет] уважать и сострадать.

2. Помогает другим: человек терпеливый, отзывчивый, внимательный к мелочам, всегда готовый помочь; благодаря таким людям наш мир становится намного добрее, потому что гуманные люди, или, по-другому, добрые люди, всегда готовы помочь, поддержать в любой жизненной ситуации; такой человек не пройдет мимо нуждающегося в помощи и попытается сделать все возможное; На самом деле гуманность - это очень положительное качество, которое характерно людям, любящим других, всегда готовым прийти на помощь; Такие люди уважают окружающих и не оставят их в беде, потому что всегда попытаются помочь всеми силами; Люди, которым не все равно на окружающих, которые не могут пройти мимо и не помочь, которые с пониманием, уважением и «на равных» относятся к любому человеку независимо от возраста, пола и ориентации, - это и есть гуманные люди; Конечно, это не обязательно те, кто откладывают все свои дела и идут спасать мир, но они все равно не безучастны; Следовательно, гуманным человеком можно назвать того человека, который ценит жизнь, как человеческую, так и любого другого существа, и который всегда готов прийти на помощь нуждающемуся, выслушать и поддержать, который ценит и уважает природу; Многие готовы взять на себя ответственность за брошенных животных на улице, помочь прохожим на улице, охранять природу и учувствовать в волонтерской деятельности; Я считаю, что гуманный человек - это тот, кто не думает о своей выгоде, не делает что-то ради себя, а думает о других, сочувствует, переживает и старается помочь окружающим его людям; Такого человека отличает желание помочь, умение сострадать и отзывчивое отношение; Конечно, это проявляется не только в отношениях с людьми, это также касается природы и всего живого; Готовый помочь людям; Для кого-то гуманный человек - тот, кто заботится о своих близких, для кого-то - тот, кто помогает животным; Для меня же гуманный человек - тот, кто умеет и не боится проявлять доброту, сострадание и заботу, стремится не причинить вред, готов оказать помощь, никогда не ставит себя выше других; Гуманные люди готовы помочь нуждающимся, не ожидая ничего взамен; Гуманисты всегда ценят счастье, и если они готовы помочь, то это не «для галочки», а от сердца; Он всегда постарается помочь в трудной жизненной ситуации; Так или иначе, гуманному человеку свойственны гуманные поступки - помощь кому-то, проявление эмпатии; Чтобы стать гуманным человеком, необходимо постоянно и целенаправленно работать над собой. Нужно иметь стремление прийти на помощь тому, кто в ней нуждается.

3. Не проявляет жесткость и не вредит другим: Гуманный человек в моем понимании - это человек, который никогда по своей воле не навредит живому существу; Такой человек умеет проявлять сострадание к другим людям и не станет совершать действий, которые могут навредить другим; Я считаю, что на сегодняшний день существует множество гуманных людей, а именно таких: уважающие других людей, не причиняющие другому человеку вреда; Гуманный человек обладает эмпатией к людям, не совершает поступки против личности; Если и говорить о гуманном человеке, то я считаю, это тот, кто знает границы и намеренно, с плохими намерениями, не причиняет вред другим; Гуманный человек никогда не совершит плохого поступка, намеренной подлости или предательства; Он стремится не причинять человеку и окружающей среде вреда, а решить все мирным словом и поступать справедливо; Гуманный человек - это тот, который не может причинить вреда живому существу; Для меня же гуманный человек - тот, кто умеет и не боится проявлять доброту, сострадание и заботу, стремится не причинить вред, готов оказать помощь, никогда не ставит себя выше других; Гуманный человек всегда поступает так, чтобы не навредить другим, однако всегда честен и справедлив; Гуманный человек - тот, кто стремится не навредить людям, однако мыслит справедливо; Для меня гуманный человек - это тот, кто хорошо и уважительно относится к окружающим его людям. Его поступки не приносят вреда обществу, а иногда даже оказывают на него хорошее влияние; Не будет жесток к другим, не будет наказывать человека больше, чем он того заслуживает; Быть гуманным человеком - значит поступать гуманно, стремиться не причинять вреда живым существам, помнить о достоинстве людей, быть добросердечным в своих действиях, но справедливым; Гуманный человек искренне любит и уважает других людей, он не совершает дурного поступка, намеренной подлости или предательства; На мой взгляд, гуманный человек это человек, проявляющий уважение к личности других людей, а также стремящийся своими поступками нанести как можно меньше вреда другим людям; Гуманный человек никогда не начнет решение проблем с оскорблений. Такой человек будет с уважением относиться к другим людям, и если он где-то был не прав, то просто извинится, а не начнет словесную перепалку, которая может перейти в драку.

4. Добр по отношению к другим: Благодаря таким людям наш мир становится намного добрее, потому что гуманные люди, или, по-другому, добрые люди, всегда готовы помочь; На мой взгляд, это тот человек, который 
относится к окружающему миру с любовью и добротой; Гуманный человек всегда относится к другим с уважением, эти люди всегда добры и внимательны к другим, о чем свидетельствуют их гуманные поступки; Таким образом, можно сказать, что гуманность - это важное качество, которое определяет хороших и добрых людей, которым не безразлично на беды других; Для меня же гуманный человек - тот, кто умеет и не боится проявлять доброту, сострадание и заботу, стремится не причинить вред, готов оказать помощь, никогда не ставит себя выше других. Для меня это понятие очень тесно связано с честностью и справедливостью; Они всегда делятся своим добром; Гуманность, в моем понимании, это любовь, внимание и уважение к человеку, доброе отношение ко всему и человеколюбие. Гуманным человек является, если все вышеперечисленные качества у него есть, то есть он относится с добротой ко всему живому и неживому; Как же охарактеризовать личность, которая на протяжении всей жизни старается жертвовать собой ради окружающих или же с добротой, с сочувствием относится к ним, то есть совершает гуманные поступки? Я думаю, что такого человека можно назвать гуманным, и всем людям следует стремиться к воспитанию в себе гуманности; Гуманный человек - это человек, который с пониманием и добротой относится к другим людям; На мой взгляд, гуманный человек - тот, который относится к другим людям с уважением, любовью, добротой; тот, который заботится о людях; добродушный к людям; человек, который может направить свою доброту другому, независимо от того, как он относится к нему; человек, проявляющий внимание и заботу к другим людям; человек, который проявляет внимание и уважение к другим людям.

5. Любит окружающих: На мой взгляд, это тот человек, который относится к окружающему миру с любовью и добротой; На самом деле, гуманность - это очень положительное качество, которое характерно для людей, любящих других, всегда готовых прийти на помощь; В классическом понимании гуманный человек - человеколюбивый, с уважением относящийся к личности человека, но в большинстве своем это утопия, мы можем когото недолюбливать, хотя и не показываем это в большинстве случаев; По моему мнению, гуманный человек это тот, кто любит людей, ставит их в приоритет; Я считаю, что гуманный человек на настоящее время - это та личность, которая, невзирая на различные отрицательные поступки человечества, все равно остается добродушной и любит этот мир; На мой взгляд, гуманный человек - тот, который относится к другим людям с уважением, любовью, добротой; Гуманный человек искренне любит и уважает других людей, он не совершает дурного поступка, намеренной подлости или предательства. Сейчас очень мало таких людей.

6. Понимает других людей и принимает их такими, какие они есть: Гуманный человек уважает человеческую личность, принимает ее такой, какая она есть; Люди, которым не все равно на окружающих, которые не могут пройти мимо и не помочь, которые с пониманием, уважением и «на равных» относятся к любому человеку независимо от возраста, пола и ориентации, - это и есть гуманные люди; Гуманный человек обладает эмпатией к людям, не совершает поступки против личности; Гуманный человек - это именно тот, кто будет стараться понимать и принимать другого, независимо от того, какой он; Гуманный человек всегда уважает личность другого, он может сочувствовать другому и относиться с пониманием; Гуманный человек всегда будет относиться к выбору, вере, каким-то другим убеждениям другого человека абсолютно спокойно. Такой человек никогда не осудит твой выбор; Человек, который уважает, любит и понимает другого; Понимающий по отношению к другим людям человек; Человек, который умеет понимать другого человека.

7. Жертвует собой ради других: Гуманный человек честен и бескорыстен, он готов пожертвовать своим временем, своими возможностями ради блага других; По моему мнению, гуманный человек - это тот, кто любит людей, ставит их в приоритет; Я считаю, что гуманный человек - это тот, кто не думает о своей выгоде, не делает что-то ради себя, а думает о других, сочувствует, переживает и старается помочь окружающим его людям; Для меня же гуманный человек - тот, кто умеет и не боится проявлять доброту, сострадание и заботу, стремится не причинить вред, готов оказать помощь, никогда не ставит себя выше других; Как же охарактеризовать личность, которая на протяжении всей жизни старается жертвовать собой ради окружающих или же с добротой, с сочувствием относится к ним, то есть совершает гуманные поступки? Я думаю, что такого человека можно назвать гуманным, и всем людям следует стремиться к воспитанию в себе гуманности.

8. Бережет природу и животных: Следовательно, гуманным человеком можно назвать того человека, который ценит жизнь, как человеческую, так и любого другого существа, и который всегда готов прийти на помощь нуждающемуся, выслушать и поддержать, который ценит и уважает природу; Многие готовы взять на себя ответственность за брошенных животных на улище, помочь прохожим на улице, охранять природу и участвовать в волонтерской деятельности; Гуманный человек - это человек, который любит и уважает других людей, заботится о них, подоброму относится ко всему живому; Он стремится не причинять человеку и окружающей среде вреда, а решить все мирным словом и поступать справедливо; Такого человека отличает желание помочь, умение сострадать и отзывчивое отношение. Конечно, это проявляется не только в отношениях с людьми, это также касается природы и всего живого; Для кого-то гуманный человек - тот, кто заботится о своих близких, для кого-то - тот, кто помогает животным; Выходит, что человек является гуманным, если он с добротой относится ко всему живому.

9. Делает мир лучше: Благодаря таким людям наш мир становится намного добрее, потому что гуманные люди, или, по-другому, добрые люди, всегда готовы помочь, поддержать в любой жизненной ситуации; Мысли и поступки такого человека направлены на то, чтобы принести как можно больше пользы людям, сделать мир чуточку лучше и добрее; Он старается сделать лучше все, что его окружает, отдает дань уважения каждому бескорыстно; Для меня гуманный человек - это тот, кто хорошо и уважительно относится к окружающим его людям. Его поступки не приносят вреда обществу, а иногда даже оказывают на него хорошее влияние; К примеру, гуманный человек всегда будет поступать так, чтобы другим стало лучше.

10. Совершает гуманные поступки: Гуманные люди совершают гуманные поступки; Очень легко понять, гуманный человек или нет, нужно просто посмотреть на его поведение; Такая личность совершает гуманные 
поступки, то есть содействует окружающим в решении проблем; Как же охарактеризовать личность, которая на протяжении всей жизни старается жертвовать собой ради окружающих или же с добротой, с сочувствием относится к ним, то есть совершает гуманные поступки? Я думаю, что такого человека можно назвать гуманным, и всем людям следует стремиться к воспитанию в себе гуманности; Быть гуманным человеком - значит поступать гуманно, стремиться не причинять вреда живым существам, помнить о достоинстве людей, быть добросердечным в своих действиях, но справедливым.

11. Проявляет сострадание: Такой человек умеет проявлять сострадание к другим людям и не станет совершать действий, которые могут навредить другим; Я считаю гуманность одним из важнейших качеств человека, гуманный человек обладает той самой силой сострадания и доброжелательности к любому человеку.

12. Уважает себя: Но я считаю, что гуманный человек не только должен уважать других, но и в первую очередь уважать себя; Для меня гуманный человек - это личность, которая уважает себя, ведь без этого человек не может уважать других, окружающих его людей.

В некоторых текстах также присутствуют единичные пояснения о том, что гуманный человек: поддерживает баланс в обществе (Гуманный человек в обществе поддерживает его баланс); принимает мнение других (Такой индивид знает, что у каждого есть свое мнение и оно может отличаться от его, но он принимает его; Ему свойственно уважение чужого мнения); заслуживает уважения (Но несмотря на то, что в наше время остается мало гуманных людей, все же существуют те, кто делает поступки, начиная с самых малых... Я считаю, что такие люди заслуживают большого уважения); испытывает муки совести (Их скорее всего будет мучать совесть, если они не помогут или поступят неправильно по отношению к кому-то, кто этого не заслуживает). Реципиенты также указали, что гуманным человеком можно стать: Чтобы стать гуманным человеком, необходимо постоянно и целенаправленно работать над собой.

Зона общей оценки концепта ГУМАННЫЙ ЧЕЛОВЕК выражена прилагательными и словосочетаниями с положительной коннотацией: Хороший (4); Таким образом, можно сказать, что гуманность - это важное качество, которое определяет хороших и добрых людей, которым небезразлично на беды других; Очень хорошо, что люди сейчас более человечны, чем были, например, 20-30 лет назад. Помимо положительных оценочных реакций, реципиентами также была приведена единичная негативная реакция: честолюбивый.

При определении типов оценок, выявленных в ходе анализа данных лингвистических экспериментов, мы опираемся на классификацию Н. Д. Арутюновой (1988, с. 75-76).

Этическая оценка:

1) добрый и любящий других людей: добрый (20); человеколюбивый (3); человечный (3); любящий (2); любящий людей; относящийся с любовью к другим;

2) милосердный и благородный: милосердный (2); Гуманному человеку присущи следующие качества: милосердие, сострадание, человеколюбие, альтруизм; По моему мнению, гуманный человек имеет такие качества, как человеколюбие, милосердие и сострадание; Гуманным человеком называют доброго, благородного, великодушного, отзывчивого человека;

3) отзывчивый и бескорыстный: отзывчивый (11), отзывчив; человек терпеливый, отзывчивый, внимательный к мелочам, всегда готовый помочь; На мой взгляд, гуманным человеком можно назвать отзывчивого, снисходительного к другим людям и их поступкам; Такого человека отличает желание помочь, умение сострадать и отзывчивое отношение; Кто же такой гуманный человек? Для меня это человек, который отзывчиво, чутко относится к людям, проникнутый заботой к ним; Гуманные люди готовы помочь нуждающимся, не ожидая ничего взамен; На мой взгляд, гуманным человеком можно назвать отзывчивого, снисходительного к другим людям и их поступкам; Гуманный человек честен и бескорыстен, он готов пожертвовать своим временем, своими возможностями ради блага других; Он старается сделать лучше все, что его окружает, отдает дань уважения каждому бескорыстно;

4) уважительный: уважительный (4); уважительный по отношению к другим; уважающий окружающих; относящийся с уважением к ним [людям]; уважительно относящийся человек;

5) способный сострадать: сострадательный (3), способный сострадать.

Психологическая оценка:

1) внимательный и заботливый: внимательный (3); проникнутый вниманием; внимательный к мелочам; внимательный к чужим проблемам; Кто такой гуманный человек? На мой взгляд, это человек, который чуток, внимателен и заботлив по отношению к другим; Для меня же гуманный человек - тот, кто умеет и не боится проявлять доброту, сострадание и заботу, стремится не причинить вред, готов оказать помощь, никогда не ставит себя выше других; Для меня это человек, который отзывчиво, чутко относится к людям, проникнутый заботой к ним; относящийся [к людям] с заботой об их благе;

2) чуткий и понимающий: понимающий (2); относящийся чутко к людям (2); эмпатичный; умеющий читать ситуацию; снисходительный; считающийся с мнением других;

3) а также единичные реакции-оценки: душевный (2), терпимый (2), толерантный (2), помогающий (2), сердечный (2), добродушный, добросердечный, [относящийся] без злого умысла.

Нормативная оценка:

1) честный и справедливый: Он стремится не причинять человеку и окружающей среде вреда, а решить все мирным словом и поступать справедливо; Для меня же гуманный человек - тот, кто умеет и не боится проявлять доброту, сострадание и заботу, стремится не причинить вред, готов оказать помощь, никогда не ставит себя выше других. Для меня это понятие очень тесно связано с честностью и справедливостью; Гуманный человек - тот, кто стремится не навредить людям, однако [стремится] мыслить справедливо; Гуманный человек 
всегда поступает так, чтобы не навредить другим, однако всегда честен и справедлив; Быть гуманным человеком - значит поступать гуманно, стремиться не причинять вреда живым существам, помнить о достоинстве людей, быть добросердечным в своих действиях, но справедливым;

2) идеальный: В поступках гуманного человека нет ничего плохого, никакой злости, обиды или агрессии, наоборот, это картинка идеального человека, который делает все или помогает всем вокруг. Политика такого человека такая: он не пройдет мимо чужой беды, а, наоборот, поможет и будет переживать за человека, как за себя. Без этого качества в людях не получится построить высоконравственное, дружное общество;

3) нормативные оценки: искренний (4), воспитанный (2), чистосердечный, правильный, стандартный, высший, честный.

Количественная оценка выражена преимущественно реакциями, в которых реципиенты указывают на небольшое количество гуманных людей в обществе: $K$ сожалению, гуманных людей очень мало, но, тем не менее, они есть; Но несмотря на то, что в наше время остается мало гуманных людей, все же существуют те, кто делает поступки, начиная с самых малых; В современном мире мало кого можно назвать гуманным человеком; Очень редко можно увидеть тех людей, кто возьмет и предложит свою помощь бабушке; Гуманный человек искренне любит и уважает других людей, он не совершает дурного поступка, намеренной подлости или предательства. Сейчас очень мало таких людей. Однако среди ответов присутствует также противоположная единичная характеристика, согласно которой гуманных людей немало: Я считаю, что в современном обществе осталось еще немало гуманных людей.

Среди ответов реципиентов также присутствуют оценочные реакции, которые относятся к теологической оценке (выражена реакциями: осознанный) и интеллектуальной оценке (выражена реакциями: разумный (3), умный (2)).

В полученных оценочных характеристиках также можно выделить противопоставление современного и прошлого поколений при помощи сравнительного оборота «более/менее», в котором параметром выступает степень гуманности человека: Поколение наших родителей и их родителей можно назвать менее гуманным, потому что они жили по «шаблону». Все одевались, вели себя одинаково. Поэтому любое отклонение от общей нормы они считают именно отклонением. Многих людей этого поколения нельзя назвать гуманными. Чего не скажешь о людях, рожденных в конце 20 и 21 веке. Молодые люди более гуманны; Очень хорошо, что люди сейчас более человечны, чем были, например, 20-30 лет назад.

Данные, полученные в результате использования метода дописывания фразы «Гуманного человека я могу сравнить с...», позволили раскрыть содержание образного слоя аксиологического концепта ГУМАННЫЙ ЧЕЛОBEK. Анализ результатов показал, что способы, которыми реципиенты описывают «гуманного человека», возможно разделить на пять нижеследующих типов образов:

1. Образ матери, бабушки: мать Тереза; матерью, для которой все ее дети равны и любимы одинаково; мамой, искренне любящей своего ребенка; добродушная бабушка, которая все простит своему внуку.

2. Образы социальной роли и модели поведения: руководитель; руководители приютов для животных; люди, занимающиеся благотворительностью; герой; альтруист.

3. Персонифицированные образы: Аристотель, Пушкин, мать Тереза, Владимир Одоевский.

4. Образы, связанные с животным миром: котенок; волк в стае: он также надежен, и он не станет нападать на ближнего; собака (2); воспитанная собака; верная собака; лев, он такой же справедливый, честный и милосердный.

5. Образы сенсорного восприятия (теплый свет (2), свет).

А также единичные реакции, в которых вербализированы образы, связанные с окружающим миром (облако); образы, связанные с психоэмоциональным состоянием (ощущение комфорта и спокойствия); образы, связанные с выражением нормативности и силы (закон, мораль, сила), и образы, связанные с ощущением поддержки (последняя надежда современного мира, поддержка).

На основании проведенного исследования ниже представлена визуализация структуры аксиологического концепта ГУМАННЫЙ ЧЕЛОВЕК в обыденном сознании современных носителей русской лингвокультуры, составленная на базе данных проведенной серии лингвистических экспериментов. Поскольку анализ полученных материалов показал, что граница между понятийным и аксиологическим слоем данного концепта размыта, мы посчитали необходимым отразить этот факт волнистой линией между соответствующими колонками в Таблице 1.

Как видно из таблицы, ядерные признаки концепта ГУМАННЫЙ ЧЕЛОВЕК в обыденном сознании носителей русской лингвокультуры отличаются от аналогичных признаков, выделенных на основании изучения лексикографических источников. К последним относятся следующие понятийные признаками: 1) «любит других людей»; 2) «оказывает помощь и моральную поддержку другим людям»; 3) «относится с уважением к человеческому достоинству и личности».

Признак «любит других людей» в обыденном создании уходит на ближнюю периферию (см. Таблицу 1), его заменяет признак «ценит и уважает человеческую личность и ее права». Данный признак выделяется и в структуре концепта ГУМАННЫЙ ЧЕЛОВЕК, созданной на основании лексикографических источников, однако в ней он занимает третью позицию. Второй признак («оказывает помощь и моральную поддержку другим людям») в обыденном сознании сохраняется, однако он конкретизируется до признака «помогает другим». В содержании понятийного слоя концепта ГУМАННЫЙ ЧЕЛОВЕК в обыденном сознании к числу ядерных признаков также относятся признаки «не проявляет жесткость и не вредит другим» и «добр по отношению к другим», которые не выделяются в структуре концепта, созданной на основании лексикографических источников. 
Таблица 1. Структура аксиологического концепта ГУМАННЫЙ ЧЕЛОВЕК в обыденном сознании современных носителей русской лингвокультуры

\begin{tabular}{|c|c|c|}
\hline Понятийный слой & Аксиологический слой & Образный слой \\
\hline $\begin{array}{l}\text { 1. Ценит и уважает человеческую } \\
\text { личность и ее права. } \\
\text { 2. Помогает другим. } \\
\text { 3. Не проявляет жесткость и не вредит } \\
\text { другим. } \\
\text { 4. Добр по отношению к другим. } \\
\text { 5. Любит окружающих. } \\
\text { 6. Понимает других людей и прини- } \\
\text { мает их такими, какие они есть. } \\
\text { 7. Жертвует собой ради других. } \\
\text { 8. Бережет природу и животных. } \\
\text { 9. Делает мир лучше. } \\
\text { 10. Совершает гуманные поступки. } \\
\text { 11. Проявляет сострадание. } \\
\text { 12. Уважает себя. }\end{array}$ & 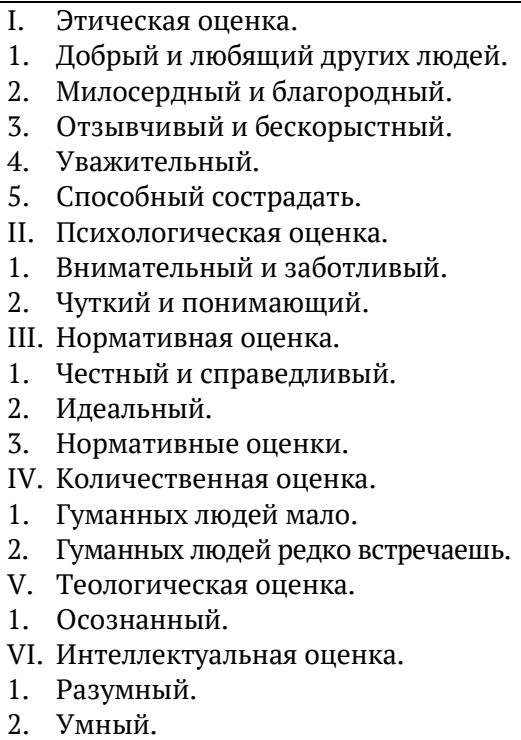 & $\begin{array}{l}\text { 1. Образ матери, бабушки. } \\
\text { 2. Образы социальной роли и модели } \\
\text { поведения. } \\
\text { 3. Персонифицированные образы. } \\
\text { 4. Образы, связанные с животным } \\
\text { миром. } \\
\text { 5. Образы сенсорного восприятия. }\end{array}$ \\
\hline
\end{tabular}

\section{Заключение}

Таким образом, мы приходим к следующим выводам. В структуре аксиологического концепта ГУМАННЫЙ ЧЕЛОВЕК выделяются понятийный, аксиологический и образный компоненты, при этом между понятийным и аксиологическим слоями нет четкой границы. Наибольшее выражение в ценностном слое получил этический тип оценки.

Анализ лексикографического материала показал, что на разных этапах жизненного цикла базовыми понятийными признаками концепта были: «образованный, культурный» (середина XIX в. и первая половина XX в.), «внимательный к чужой личности, отзывчивый» (вторая половина XX в.), «человечный, относящийся с уважением к человеческому достоинству» (рубеж XX-XXI вв.). Изучение современных лексикографических данных позволило выделить три базовых понятийных признака в содержании концепта ГУМАННЫЙ ЧЕЛОВЕК: 1) «любит других людей»; 2) «оказывает помощь и моральную поддержку другим людям»; 3) «относится с уважением к человеческому достоинству и личности».

Анализ данных проведенных лингвистических экспериментов показал, что на современном этапе развития концепта ГУМАННЫЙ ЧЕЛОВЕК в обыденном сознании носителей русской лингвокультуры к базовым понятийным признакам относятся: 1) «уважительное отношение к человеческой личности и осознание ее ценности»; 2) «помощь другим»; 3) «непричинение вреда»; 4) «доброе отношение к другим людям».

Данные проведенного исследования подтверждают, что русская традиционная и книжно-письменная лингвокультуры основываются на понятии любви к ближнему, помощи и жертвенности, все это - неотъемлемая часть русской культуры в принципе и христианской, православной культуры в частности. Эти установки национальной культуры отразились на содержании концепта ГУМАННЫЙ ЧЕЛОВЕК.

Перспективой дальнейшего исследования является привлечение данных других языков и анализ концепта ГУМАННЫЙ ЧЕЛОВЕК с позициЙ контрастивной лингвокультурологиИ. Важным представляется также изУчение смежных концептов ГУМАННОСТЬ, ГУМАННЫЙ ПОСТУПОК и ГУМАННОЕ ОТНОШЕНИЕ.

\section{Источники | References}

1. Алефиренко Н. Ф. Лингвокультурология: ценностно-смысловое пространство языка. М.: Флинта, 2016.

2. Арутюнова Н. Д. Истина. Добро. Красота: взаимодействие концептов // Логический анализ языка. Языки эстетики: концептуальные поля прекрасного и безобразного / отв. ред. Н. Д. Арутюнова. М., 2004.

3. Арутюнова Н. Д. Типы языковых значений: оценка, событие, факт. М.: Наука, 1988.

4. Белинский В. Г. Собрание сочинений: в 9-ти т. М.: Художественная литература, 1982. Т. 9. Письма 1829-1848 годов. URL: http://az.lib.ru/b/belinskij_w_g/text_1848_pisma.shtml

5. Береснева В. А. Ассоциативное поле аксиологического концепта ХОРОШИЙ ЧЕЛОВЕК // Материалы 54-й Международной научной студенческой конференции МНСК-2016. Языкознание. Новосибирск: ННИГУ, 2016.

6. Большой толковый словарь русского языка / гл. ред. С. А. Кузнецов. СПб.: Норинт, 2003. URL: http://new. gramota.ru/spravka/library/349-slovari-1

7. Воркачев С. Г. Счастье как лингвокультурный концепт. М.: Гнозис, 2004.

8. Даль В. И. Толковый словарь живого великорусского языка. М.: Цитадель, 1998. URL: http://new.gramota.ru/ spravka/library/349-slovari-1 
9. Долевец С. Н. Динамика морально-этических концептов СКУПОСТь и ЩЕДРОСТЬ в русском литературном языке XIX - начала XXI века: автореф. дисс. ... к. филол. н. Ростов н/Д, 2008.

10. Ефремова Т. Ф. Новый словарь русского языка. Толково-словообразовательный. М.: Русский язык, 2000. URL: https://www.efremova.info

11. Кирилов Н. С. Карманный словарь иностранных слов, вошедших в состав русского языка, издаваемый Н. Кириловым. СПб.: Типография Губернского правления, 1845.

12. Лукашова О. Ю. Концепт ДРУГ в русском языке // Методические проблемы когнитивной лингвистики / под ред. И. А. Стернина. Воронеж, 2001.

13. Мархиева Т. К. Отражение концепта «человек» во фразеологических единицах, номинирующих социальные характеристики человека // Lingua-universum. 2011. № 6.

14. Мокрушина Е. Ю. Концепт «добрый» как этический феномен лингвокультуры: на материале английского языка: автореф. дисс. ... к. филол. н. Кемерово, 2008.

15. Наумова Н. Г. Объективация концепта «современная девушка» в языковом сознании молодых людей г. Кирова // Современные тенденции и инновации в области гуманитарных и социальных наук: мат. I Междунар. науч.практ. конф. (г. Йошкар-Ола, 31 мая 2016 г.). Йошкар-Ола: Марийский государственный университет, 2016.

16. Национальный корпус русского языка (НКРЯ). 2021. URL: http://www.ruscorpora.ru

17. Никитина М. Ю. Концептуализация милосердия: общеязыковой и идиостилевой аспекты: речевые реализации в синхронии и диахронии: автореф. дисс. ... к. филол. н. Саратов, 2014.

18. Нурова Л. Р. Семантическое пространство концепта «глупый человек» в современном английском языке // Казанская наука. 2014. № 10.

19. Ожегов С. И. Словарь русского языка. М.: ОГИЗ-ГИС, 1949.

20. Ожегов С. И., Шведова Н. Ю. Толковый словарь русского языка: 80000 слов и фразеологических выражений. М.: Азбуковник, 2002.

21. Петросян М. И. Марксизм и гуманизм // Вопросы философии. 1955. № 3.

22. Розман И. В. Репрезентация концепта «современный человек» в массмедиа (на материале YouTube канала «вДудь») // Филологические этюды: сборник научных статей молодых ученых Всероссийской научной конференции. Саратов, 2021.

23. Сандагийн Э. Основные версии гуманизма // Вызовы современности и философия: мат. «круглого стола», посвященного Дню философии ЮНЕСКО / под общ. ред. И. И. Ивановой. Бишкек, 2004. URL: http://anthropology. $\mathrm{ru} / \mathrm{ru} /$ text/sandagiyn-e/osnovnye-versii-gumanizma

24. Словарь Академии Российской: в 6-ти ч. / под ред. Г. Р. Державина. СПб.: При Императорской академии наук, 1794. Ч. 6.

25. Срезневский И. И. Материалы для словаря древнерусского языка по письменным памятникам: в 3-х т. СПб.: Издание Отделения рус. яз. и словесности Императорской академии наук, 1893. Т. 3.

26. Толковый словарь русского языка: в 4-х т. / под ред. Д. Н. Ушакова. М.: Русские словари, 1994. Т. 1. URL: http://new.gramota.ru/spravka/library/349-slovari-1

27. Фасмер М. Этимологический словарь русского языка: в 4-х т. М., 1986. Т. 1.

28. Ципотан Д. С. Аксиологический концепт «плохой человек» в региональной ценностной картине мира (на материале лингвистического эксперимента в детской и подростковой фокус-группах пгт. Шушенское Красноярского края) // XXVIX Международный научно-исследовательский конкурс: сборник статей. Пенза: Наука и просвещение, 2019.

29. Черных П. Я. Историко-этимологический словарь современного русского языка: в 2-х т. 1993. Т. 1.

30. Шанский Н. М. Этимологический словарь русского языка: в 2-х т. М.: Изд-во Московского университета, 1972. Т. 1.

\section{Информация об авторах | Author information}

RU Бирюлина Екатерина Андреевна ${ }^{1}$

${ }^{1}$ Сибирский федеральный университет, г. Красноярск

EN Biryulina Ekaterina Andreevna ${ }^{1}$

${ }^{1}$ Siberian Federal University, Krasnoyarsk

${ }^{1}$ ekaterinabir2015@gmail.com

\section{Информация о статье | About this article}

Дата поступления рукописи (received): 16.12.2021; опубликовано (published): 31.01.2022.

Ключевые слова (keywords): лингвокультурология; аксиологический концепт; гуманный человек; понятийный признак; этическая оценка; linguoculturology; axiological concept; humane person; notional feature; ethical assessment. 